\title{
Hybrid graduate program in optical engineering
}

\section{Banmali Rawat}

Banmali S. Rawat, "Hybrid graduate program in optical engineering," Proc. SPIE 9663, Eighth International Topical Meeting on Education and Training in Optics and Photonics, 966312 (6 October 2003); doi: 10.1117/12.2208499

SPIE Event: Eighth International Topical Meeting on Education and Training in Optics and Photonics, 2003, Tucson, Arizona, United States 


\title{
Hybrid graduate program in optical engineering
}

\author{
Banmali S. Rawat \\ Department of Electrical Engineering, University of Nevada, Reno, NV 89557, U.S.A. \\ Tel: (775)784-1457, Fax: (775)784-6627, e-mail: rawat@ee.unr.edu
}

\begin{abstract}
A unique graduate program in optical engineering by combining optical and microwave courses has been developed in the University of Nevada, Reno. The advantage of such a hybrid program is better job opportunities in a tight job market as these students are suitable for both $\mathrm{RF} /$ microwaves and Optical industries.

(C)2003 Optical Society of America

OCIS codes: (060.4510) Optical communications; (060.2330) Fiber optic communications
\end{abstract}

The idea of developing a hybrid program by combing optical and microwave courses was conceived few years back while developing an optical engineering graduate program. It was realized that the job opportunities in optical engineering and science area are not still at that level as RF/microwaves and other areas of electrical engineering. Also, the students with optical engineering degrees have to compete with physics and optics students. This further diminishes the job opportunities for them. The microwaves and optical engineering areas are so close to each other that the students do not have difficulty in learning both the areas simultaneously.

Based on this concept a hybrid graduate program with the following courses has been developed at the University of Nevada, Reno.

\section{Optical Courses}

EE 645 Fiber Optics Lab

EE 648 Fundamental of Optical Fiber Communication

EE 741 Optical Fiber Communication

EE 742 Optical Fiber Sensors \& Applications

EE 743 Optical Fiber Networking

EE 791- Research Topics

EE 793 Independent Study

EE 797 Thesis

EE 799 Dissertation

Phys 725 Laser Physics

Required Course for all EE students

EE 782 Random Signal Analysis

Credits
1
3
3
3
3
3
3
6
24
3

RF/Microwave Courses

EE 650 Microwave Lab

EE 652 Microwave Engineering

EE 751 Antenna Theory \& Design

EE 752 Advanced EM Analysis

EE 754 Microwave Semiconductor Devices

EE 756 Microwave Integrated Circuits

EE 757 Microwave Communication Systems

$\begin{array}{cc}\text { Credits } \\ \\ 1 \\ \\ 3 \\ 3 \\ 3 \\ & 3 \\ & 3 \\ & 3\end{array}$

3

All graduate students are supposed to take EE 645, 648. For MS degree they have to take 9 more credits in optical area, 9 credits in RF/Microwave area and $3 \mathrm{EE}$ required credits. Thus total required course credits for MS degree are 24 and 6 credits of thesis making total of 30 credits [1]. Students are also encouraged to complete summer internship in an optical industry or research laboratory. For Ph.D. after BSEE degree, a student is supposed to take 72 total credits including 24 dissertation credits. In that case the students have to take 33 credits in optical area, 12 credits in rf/microwave area and $3 \mathrm{EE}$ required credits. These credits may include independent study and research topics credits also. Any student going for Ph. D. program after MSEE degree has to complete 12 credits in optical area, 9 credits in $\mathrm{rf} /$ microwave and $3 \mathrm{EE}$ required credits. With this course structure, students are fairly well prepared for both microwaves and optical industries. For thesis and dissertation work our students have option to go abroad. We have established a graduate student exchange program with the universities and research institutes in Germany and Japan. We are in the process of establishing some collaborative research activities with some universities and research laboratories within US also. Advantages, disadvantages and difficulties in the process of such a hybrid program will be presented in detail during the conference.

\section{References}

[1] General Catalog, University of Nevada, Reno, 2002-2003.

Eighth International Topical Meeting on Education and Training in Optics and Photonics,

edited by Barry L. Shoop, Grover Swartzlander Jr., Proc. of SPIE Vol. 9663, 966312

(c) 2003 SPIE, OSA, ICO · doi: 10.1117/12.2208499 